\title{
Description of Atylotus kakeromaensis n. sp. from Amami-oshima Islands, Japan (Diptera, Tabanidae)
}

\author{
Hirofumi Hayakawa, * Hirosi Takahasi** and Hiroshi Suzuki*** \\ *Tohoku National Agricultural Experiment Station, Morioka, Iwate 020-01, Japan \\ **1-40-10, Hayamiya, Nerima-ku, Tokyo 176, Japan \\ ***Institute for Tropical Medicine, Nagasaki University, Nagasaki, Nagasaki 852, Japan
}

(Received: July 9, 1982)

\begin{abstract}
Atylotus kakeromaensis n. sp. is described based on the materials from Amami-oshima Islands, Japan. This species is easily distinguished from other related species by the slender middle callus on frons and the light yellowish orange abdomen with an indefinite darker median stripe.
\end{abstract}

Tabanid materials collected from Amamioshima and its neighboring islands in 19721977 by the third author, H. Suzuki, included a new species of Atylotus. This is the same species as Atylotus sp. 1 reported in the previous paper (Takahasi, 1977).

\section{Atylotus kakeromaensis n. sp.}

Female (Figs. 1 and 2): Length 11-14 mm.

Medium-size, rather slender, almost yellowish species without any distinct markings. Flagellum of antennae stout, brownish. Frons narrow with a square basal callus and a slender middle callus. Wings hyaline. Legs yellow, black or dark brown distally. Abdomen light yellowish orange with an indefinite median stripe on tergites.

Head much broader than thorax. Eyes greyish yellow to brown in dried materials, bare without bands. Ocellar tubercle absent. Frons narrow, about 5 times as high as basal width, slightly widened above, pale yellow pollinose with short black hairs. Venter slightly depressed, covered with black hairs.

* 早川博文 : 農林水産省東北農業試験場 (广020-01 岩手県盛岡市下尉川字赤平 4)

** 高橋 弘 (干176 東京都練馬区早宮 1-40-10)

*** 鈴木 博: 長崎大学熱帯医学研究所 (千852 長 崎県長崎市坂本町 12-4)
Basal and middle calli black, well separated; basal callus square; middle callus slender. Subcallus concolorous pollinose with frons. Face and cheeks pale yellow pollinose with long pale yellowish hairs.

Antennae stout, shorter than the length of head. Scape yellowish to yellowish orange with short black hairs, as long as broad, half the length of basal segment of flagellum, widened apically. Pedicel small, cup-like, concolorous with scape, covered with short black hairs. Flagellum dark brown to reddish brown except basal part which is reddish orange, rather long; basal segment compressed, about 1.5 times as long as width, tapering toward apex; dorsal process dull with some short black hairs; stylus slender and somewhat shorter than the length of basal segment, composed of 4 annulations. Maxillary palpi orangy yellow, a little shorter than proboscis; first segment short, covered with long pale yellowish hairs; second segment stout, tapering toward apex, about 3.1 times as long as subbasal width, covered with short black hairs, mixed with pale yellowish hairs ventrally and basally. Proboscis brown to dark brown, stout, about $3 / 5$ the length of head.

Thorax slightly longer than broad. Scutum and scutellum pale yellow, covered with short golden hairs and black hairs. Three longitudinal stripes on scutum paler, indistinct or 

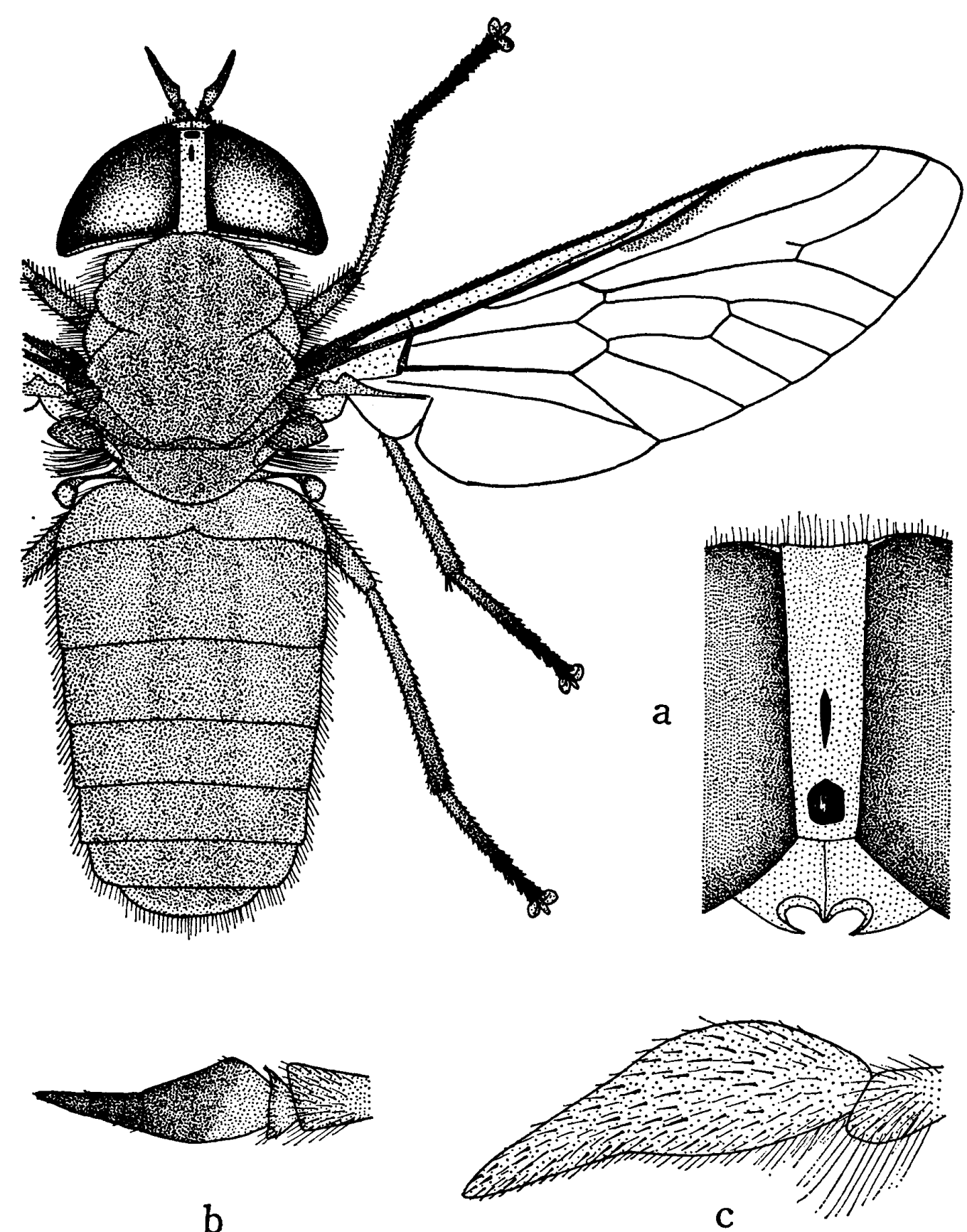

$\mathrm{b}$

C

Fig. 1 Atylotus kakeromaensis n. sp. (female) a, frons; b, antenna; c, palpus.

entirely absent. Humeral calli pale yellow with pale yellow hairs. Notopleural lobes light yellow with long pale yellow hairs, mixed with long black hairs. Some tufts of golden hairs on supraalar and postalar calli. Pleura, sternum and fore coxae pale yellow with long pale yellowish hairs.

Wings slightly shorter than body length, hyaline except some yellowish tints at base and around costal cell. Pterostigma yellow, indefinite. Veins yellowish brown; vein $R_{4}$ with rather long appendix. Cell $\mathrm{R}_{5}$ open. Halteres yellowish orange, but the knobs vivid yellow.

Legs: Femora light yellowish orange, but fore femora brownish at distal half, covered mostly with long brown hairs. Tibiae light yellowish orange, but fore femora blackish at distal half, covered mostly with long black hairs. Tarsi black to brown, covered with short black hairs.

Abdomen rather slender in shape. Dorsum 

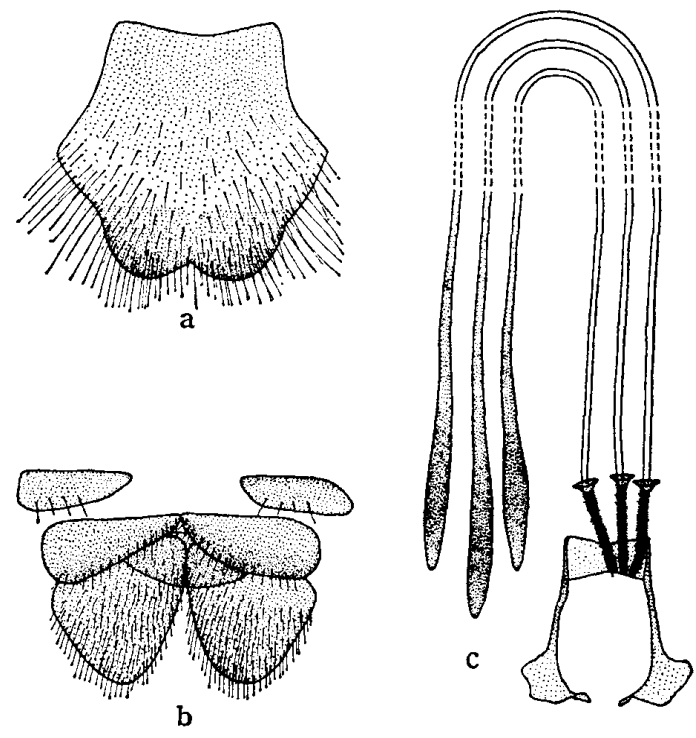

Fig. 2 Atylotus kakeromaensis 11. sp. (female)

$a$, eighth sternite; $b$, terminal segments;

$c$, genital fork and spermathecal ducts.

light yellowish orange with an indefinite darker median stripe, covered mostly with short black hairs on darker area, but mostly with golden hairs on paler area. Venter entirely light yellowish orange, covered with short golden hairs except apical segments which were covered with long black hairs.

Genitalia: Tenth tergite divided into two, rather large, triangular. Cerci roughly triangular, pointed at hind margin. Eight sternite roughly pentagon, deeply indented at hind margin. Spermatheca loosely swelling toward apex, brown pigmented apically.

Male: Unknown.

Type series: Holotype ( $\$$ ), Adachi, Setouchi-cho, Kakeroma Island, 2 August 1972, H. Suzuki leg. Paratypes: 1 , Tokuhama, Setouchi-cho, Kakeroma Island, 24 August 1973, H. Suzuki leg; 1․ Yoro, Setouchicho, Yoro Island, 7 August 1973, H. Suzuki leg; 8 \% , Kaitsu-zaki, Setouchi-cho, Amami-oshima Island, 24 July-12 August 1973,
21 July-16 September 1974, 10 August 1975, 25 July 1977, H. Suzuki leg; 3 우, Honohoshi, Setouchi-cho, Amami-oshima Island, 26 July 1973, H. Suzuki leg. Holotype and 2 paratypes are preserved in Division of Entomology, National Institute of Agricultural Sciences in Tsukuba, Ibaraki-ken. Other paratypes are also preserved in Division of Environment, Tohoku National Agricultural Experiment Station, Morioka-shi, Iwate-ken.

Distribution: Kakeroma I., Yoro I. and Amami-oshima I., Japan.

Remarks: The present species is easily distinguished from the previously known species (Murdoch and Takahasi, 1969) by the slender middle callus on frons and without distinct markings on abdomen. It is most closely allied to the Takahasi's species, Atylotus sp. 2 (Takahasi, 1977), but differs from the latter in having longer appendix on vein $\mathrm{R}_{4}$ of wings and rather smaller body size.

All of the specimens were collected by a fly net when the flies were attacking man for blood-sucking.

\section{REFERENCES}

Murdoch, W. P. and H. Takahasi (1969): The female Tabanidae of Japan, Korea and Manchuria. Mem. Entomol. Soc. Wash., 6: 1-230.

Takahasi, H. (1977): Horseflies Tabanidae. In: Animals of medical importance in the Nansei Islands in Japan (ed., Sasa, M. et al.), pp. 201210, Shinjuku-shobo, Tokyo.

$$
\begin{gathered}
\text { 摘 要 } \\
\text { アブの1 新種 Atylotus kakeromaensis } \\
\text { カケロマキイロアブの記載 }
\end{gathered}
$$

加計呂麻島, 与路島, 奄美大島で採集された雌成虫 標本に基ういて, 新種 A. kakeromaensis カケロマキ イロアブを記載した. 本種は, 中額瘤が細長く, 腹背 面が淡黄橙色で暗色の不鮮明な中央縦条があることか ら，キイロアブ属の既知種から容易に区別される. 